\title{
Four Times Weekly
}

National Cancer Institute

\section{Source}

National Cancer Institute. Four Times Weekly. NCI Thesaurus. Code C64531.

Four times per week. 